\title{
Effects of Heating Temperature and Moisture on Indirect Gasification of Rubber Wood in Closed Gasifier Chamber
}

\author{
Hiroki Homma ${ }^{*}$, Naoya Nishida² ${ }^{2}$ Akio Furuta ${ }^{2}$ \\ ${ }^{1}$ Department of Mechanical Engineering, National Institute of Technology, Matsue College, Matsue, Japan \\ ${ }^{2}$ Advanced Production and Constructions Systems Course, National Institute of Technology, Matsue College, \\ Matsue, Japan \\ Email: "homma@be.to
}

Received 3 February 2016; accepted 6 March 2016; published 9 March 2016

Copyright (c) 2016 by authors and Scientific Research Publishing Inc.

This work is licensed under the Creative Commons Attribution International License (CC BY). http://creativecommons.org/licenses/by/4.0/

(c) (i) Open Access

\begin{abstract}
Rural area in Indonesia of which electrification ratio is still low has a strong demand for off-grid electric power supply. On the other hand, Indonesia is a leading natural rubber production country and these rubber wood trees are cultivated in vast plantation farms. A rubber wood tree is woody biomass resource which can be stably supplied because a lot of trees aged more than 25 years are logged and nursery trees are planted constantly. Woody biomass is burned directly as solid fuel and the generated thermal energy can be applied only for room heating or cooking. Otherwise, direct conversion of biomass to electric energy requires a large scale equipment such as a boiler and a steam turbine, whereas gasified woody biomass can be easily handled and can have wide application. A closed gasifier chamber which was kept vacuum and fulfilled with gas yield during gasification was recently developed by the authors for indirect gasification. It was confirmed that generated gas by the gasifier is clean and can be directly used to drive an engine generator to supply electricity. In this study, planer dust of rubber wood is used as gasification feedstock for indirect gasifying in the closed gasifier chamber, and effects of heating temperature and moisture content on gasification performance are discussed to examine characteristics of the closed gasifier chamber in details.
\end{abstract}

\section{Keywords}

Indirect Gasification, Rubber Wood, Closed Gasifier Chamber, Moisture Content, Gas Component

\footnotetext{
${ }^{*}$ Corresponding author.
}

How to cite this paper: Homma, H., Nishida, N. and Furuta, A. (2016) Effects of Heating Temperature and Moisture on Indirect Gasification of Rubber Wood in Closed Gasifier Chamber. Journal of Sustainable Bioenergy Systems, 6, 1-9. 


\section{Introduction}

Economic growth in ASEAN (Association of Southeast Asian Nations) countries is significant in recent years. Primary energy demand in ASEAN is about 594 million tons of crude oil equivalent in 2013 [1]; it is up to $4.5 \%$ of the global primary energy demand [2]. Indonesia has the largest territory and population in ASEAN member countries and there are abundant deposits of fossil fuels such as coal, natural gas and oil. Indonesia fossil fuel consumption is 177 million tons of crude oil equivalent in 2013 [3]. In addition, there are abundant biomass resources of which 147 million tons are produced in a year [4]. Rubber wood is the majority of woody biomass in Indonesia. Indonesia is the second largest natural rubber production country in the world, and there are huge rubber wood plantations in Sumatra and Kalimantan. Rubber wood trees of more than 25 years old are logged for lumber in the plantation. However, 41 million tons of nursery trees are replanted every year, and thus, rubber wood logs can be supplied stably. As a result, rubber wood is the promised woody biomass for energy resource. In Indonesia, electrification rate is still low as $81 \%$ and 46 million of people mostly in rural area cannot access electricity [3] [5]. From a different viewpoint, they may be those who can easily access woody biomass resource, and are in an advantageous situation for off-grid electric power supply using biomass gasification.

The simplest way to get thermal energy is to burn woody biomass directly as solid fuel. However, the generated energy can be only used for heating or cooking. On the other hand, if we try to generate electric energy by burning woody biomass, a steam turbine generator system must be installed. Considering the above shortcomings concerning the energy produced from direct combustion of woody biomass, change of solid woody biomass to gas or liquid should be developed from a viewpoint of versatile usage. Combustible gas extraction from biomass is one of the attractive ways. Gas can be easily utilized for a wide variety of purposes. Some type of gasifiers has been developed by use of direct heating [6]-[9] or indirect heating [10]-[14] in a pilot plant scale. Direct heating is widely used for gasification because the structure is simple. Thermal energy for the gasification is supplied from combustion of a part of biomass feedstock in a gasifier. Therefore, a certain volume of air intake is inevitable for the gasification, so that generated gas yield necessarily contains $\mathrm{N}_{2}$ from air, $\mathrm{CO}_{2}$ produced from the combustion and residual $\mathrm{O}_{2}$. Such extra gases lower heating value of the gas yield per unit volume. In contrast, an indirect heating gasifier, for instance, a rotary kiln type of gasifier decomposes biomass feedstock into gas by an outside heating source. A modicum of $\mathrm{N}_{2}$ and other incombustible gases may be contained in the generated gas on account of small air intake opportunities during feedstock feeding when a gasifier is operated under ambient pressure, but nevertheless, the high caloric gas yield can be produced by an indirect heating gasifier, and further, soot formation can be suppressed by easy diffusion of gasification agent in the gasifier. The generated gases are typically used to drive an engine generator to produce electric energy. In order to drive an engine, small heating value of generated gas may need following devices. To enhance effective gas combustion, homogeneous charge compression ignition [15]-[18] and combustion in combination with other fuel [19]-[22] are contrived.

The current authors proposed a new woody biomass gasification method using a closed gasifier chamber [23] [24]. The closed gasifier chamber is a stainless steel vessel closed by flanges and used for a vacuum and pressurized vessel that is initially vacuumed and then pressurized during gasification process. This system has the following advantages: 1) gas produced in an indirect heating gasifier does not contain inert gas because of pre-vacuuming process before gasification and high calorie gas is obtained;2) reduction of tar content in gas yield is a tradeoff between increase in reaction time and deterioration of energy efficiency; 3 ) if a biomass stove is used for heat source, it is no need to supply electricity for the gasifier operation except for pre-vacuuming; 4) the gasifier can be used for a temporary gas storage tank after gasification is terminated. Thus, it can be expected that generated gas is used without any treatment to drive a small gasoline engine generator for electric power.

This system is supposed to use rubber wood for gasification feedstock and to supply off-grid electricity at rural areas in Indonesia. Several studies on gasification of rubber wood by direct heating have been reported [25] [26], but research on gasification by indirect heating is very few [27]. In order to enhance efficiency of the gasifier developed by the current authors, usage of gasification agent is considered. $\mathrm{H}_{2} \mathrm{O}$ or $\mathrm{CO}_{2}$ is often added as gasification agent for woody biomass gasifier by indirect heating. Naruse et al. [28] studied effect of gasification agent on decomposition reaction using $\mathrm{N}_{2}$ as a carrier gas in a drop tube type of gasifier heated indirectly by electric furnace. They reported that $\mathrm{H}_{2} \mathrm{O}$ was effective in gasification at the temperature of lower than $1000^{\circ} \mathrm{C}$ while $\mathrm{CO}_{2}$, in gasification above $1000^{\circ} \mathrm{C}$. This study aims to enhance gasification efficiency of the indirect heating gasifier, which was developed by the current authors and operated at temperature below $1000^{\circ} \mathrm{C}$. One 
way for enhancement of the efficiency is to use a gasification agent. According to Naruse's result mentioned above, $\mathrm{H}_{2} \mathrm{O}$ is selected as a gasification agent for this study. Heretofore, there is no study on effect of moisture content in feedstock on gasification characteristics of woody biomass under no oxygen, no carrier gas and pre-vacuumed condition. Therefore, to examine effects of heating temperature and moisture content on gasification characteristics, experiments are carried out in the closed gasification chamber using planer dust of rubber wood for gasification feedstock.

\section{Experimental Apparatus}

The closed gasifier chamber was developed by the current authors to enable gasification under no oxygen and no inert gas condition in the way that the chamber is vacuumed prior to the initiation. The chamber is heated from outside, and this condition is called indirect gasification. Therefore, a structure of gasifier is rather simple and the chamber temperature can be easily controlled as compared with a conventional fix bed type of gasifier.

The experimental apparatus is shown in Figure 1. The gasifier chamber is a cylindrical vessel of which the bottom plate is welded and is made of stainless steel. The chamber dimensions are $89.1 \mathrm{~mm}$ in outer diameter, $719.0 \mathrm{~mm}$ in height, and $3.94 \times 10^{-3} \mathrm{~m}^{3}$ in internal volume. A compound gage with a vacuum range and valves are attached to a pipe line from a flange welded to the chamber top. A vacuum pump is used to vacuum the chamber prior to gasification, and a gas sampling bag is used to collect a gas yield after experiment. Gasification feedstock is put in a stainless steel cup and is placed at the bottom of the chamber. Then, the gasification is started after the chamber is placed in an electric furnace heated at a specified constant temperature.

\section{Experimental Condition and Procedure}

Rubber wood feedstock is prepared in shape of thin pieces produced by an electric planer, of which dimensions are $7 \mathrm{~mm}$ in length, $4 \mathrm{~mm}$ in width, and $0.2 \mathrm{~mm}$ in thickness. Result of ultimate analysis, ash and heating value of rubber wood are shown in Table 1. To remove moisture, the feedstock is heated up at $105^{\circ} \mathrm{C}$ and kept at the temperature for more than 7 hours in oven. Experimental conditions are summarized in Table 2. Heating temperature is defined as preset temperature of the electric furnace. Distilled water as a gasification agent is poured over the dried feedstock of $10 \times 10^{-3} \mathrm{~kg}$ to adjust prescribed moisture content. Moisture content is defined by Equation (1) on a wet state basis.

$$
\text { moisture content }=\frac{\text { mass of distilled water }}{\text { mass of dried planer dust and distilled water }}
$$

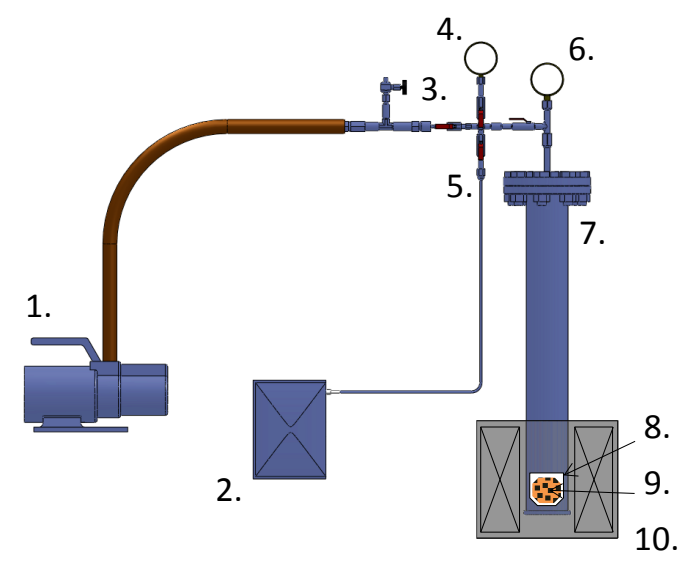
1. Vacuum pump
6. Compound gage
2. Gas sampling bag
7. Closed gasifier chamber
3. Valves
4. Vacuum gage
8. Stainless steel cup
5. Gas sampling port
9. Feedstock
10. Electric furnace

Figure 1. Experimental apparatus. 
Table 1. Results of ultimate analysis, ash and heating value of rubber wood.

\begin{tabular}{cc}
\hline $\mathrm{C}[\mathrm{wt} \%]$ & 42.3 \\
$\mathrm{H}[\mathrm{wt} \%]$ & 6.4 \\
$\mathrm{~N}[\mathrm{wt} \%]$ & 0.3 \\
$\mathrm{O}[\mathrm{wt} \%$, by difference] & \multicolumn{2}{c}{51.0} \\
\hline Ash $[\mathrm{wt} \%]$ & \multicolumn{2}{c}{1.7} \\
\hline Heating value $[\mathrm{kJ} /$ kg-dry $]$ & \multicolumn{2}{c}{18,047} \\
\hline
\end{tabular}

Table 2. Experimental conditions.

Feedstock mass $\left[10^{-3} \mathrm{~kg}\right]$

Heating temperature $\left[{ }^{\circ} \mathrm{C}\right]$

Moisture content [\%]
10

$600,700,800,900$

$0,10,20,30,40,50$

Experimental procedures are as follows:

- The feedstock sample is put into the stainless steel cup and distilled water is poured over it;

- The stainless steel cup is placed at the bottom of the chamber, then the chamber is closed with the flange;

- Air inside the chamber is suctioned by a vacuum pump until the vacuum reaches a certain level;

- The chamber is positioned in the electric furnace controlled at the preset temperature, and then gasification starts;

- When pressure inside the chamber increases and reaches plateau, small volume of generated gas is collected into the gas sampling bag to analyze gas components by a gas chromatography;

- Volume of remaining gas in the chamber is measured by downward displacement of water.

\section{Experimental Result and Discussion}

\subsection{Total Gas Yield}

Total gas yield generated per unit mass of feedstock in the gasification experiment is calculated as volume at standard ambient temperature and pressure (SATP) and shown in Figure 2. The largest gas yield of $1.32 \mathrm{~m}^{3} / \mathrm{kg}$ is obtained at heating temperature of $900^{\circ} \mathrm{C}$. It is 2.3 times larger than the gas yield volume at $600^{\circ} \mathrm{C}$. Larger moisture content causes larger gas yield in the range of moisture between $0 \%$ and $30 \%$. However, beyond this range, gas yield decreases with increase in moisture content. At $900^{\circ} \mathrm{C}$, gas yield for moisture content of $30 \%$ increases by $0.24 \mathrm{~m}^{3} / \mathrm{kg}$ from that for $0 \%$. Gas yield for $50 \%$ moisture is smaller than that for $30 \%$ and close to the result for $10 \%$. High moisture content significantly increases pressure in the chamber due to expansion of steam volume vapored from the moisture. It is considered that high pressure may suppress gasification reaction in the chamber. At heating temperature of $800^{\circ} \mathrm{C}$, total gas yield is $1.20 \mathrm{~m}^{3} / \mathrm{kg}$ for $30 \%$ moisture content. Increment of $0.38 \mathrm{~m}^{3} / \mathrm{kg}$ is made from that for $0 \%$ moisture content, which is much higher than gas yield for other moisture contents at $800^{\circ} \mathrm{C}$. In addition, the gas yield is almost same as that for $20 \%$ moisture content at $900^{\circ} \mathrm{C}$. In general, high heating temperature can produce large gas yield, but if optimal gasification agent is not used, gas yield for high heating temperature maybe less than that for optimal gasification agent at low temperature.

After an experiment has been terminated, char, mostly composed of carbon remains in the stainless steel cup. Average char yield per unit mass of feedstock is slightly dependent on heating temperature as shown in Figure 3. The char yield is $19.0 \mathrm{wt} \%$ at $900^{\circ} \mathrm{C}$ and increases to $25.0 \mathrm{wt} \%$ at $600^{\circ} \mathrm{C}$. The char yield can be an indicator for extent of decomposition reaction in a gasification process and is inversely related to gas yield. When heavy molecular hydrocarbon in decomposition products is cooled down, it is liquefied into tar. At low heating temperature, when gas yield was measured by the downward displacement method, flowing brown tar was observed together with condensed water vapor in a transparent tube. Furthermore, sticky tar adhered to the inner surface of the flange. At $900^{\circ} \mathrm{C}$, adherent tar was a little and flowing tar in the tube was also very little. This may indicate that heavy hydrocarbon is reformed into light gases at high temperature. 


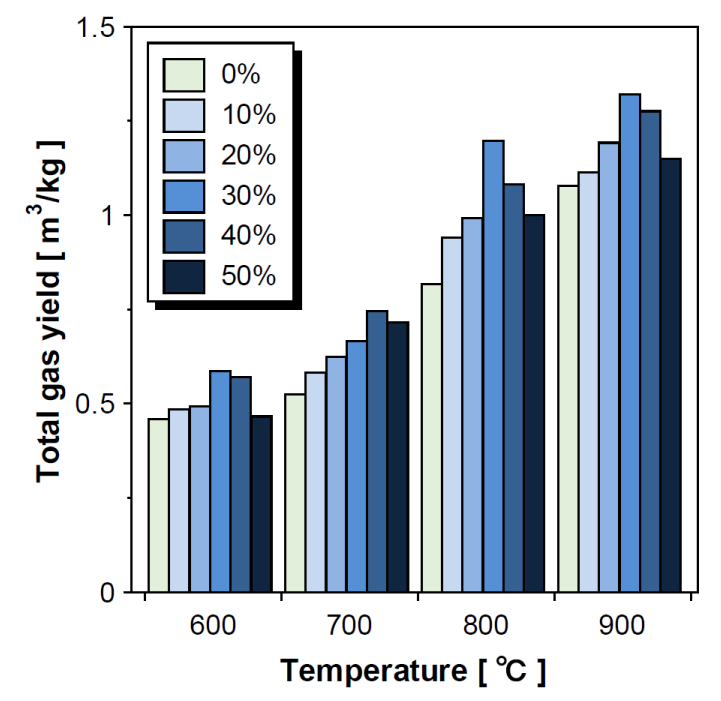

Figure 2. Total gas yield per unit mass of feedstock at SATP.

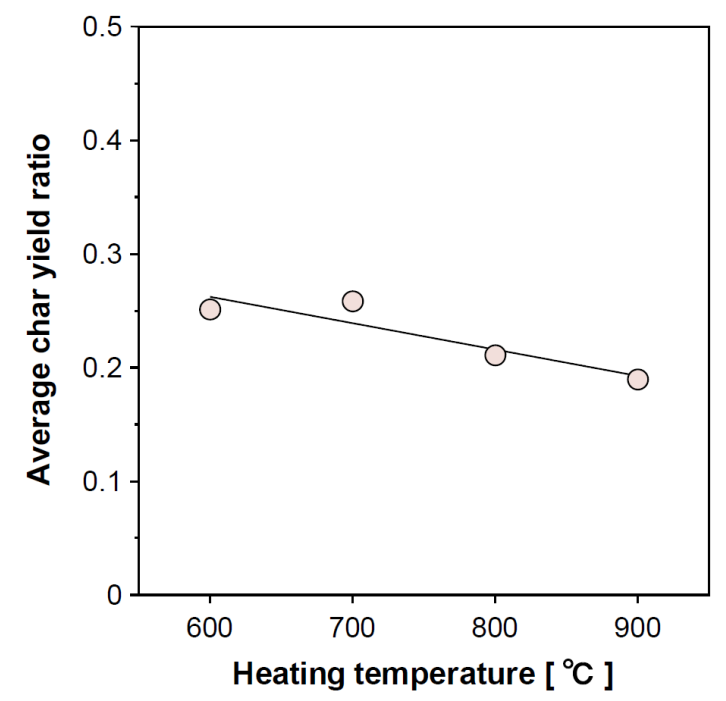

Figure 3. Average char yield ratio (char yield/feedstock mass) versus heating temperature.

\subsection{Gas Compositions and Yield of Each Gas Component}

Gas compositions of the generated gas at each heating temperature are shown in Figure 4. $\mathrm{CH}_{4}$ is $17.0 \%$ and independent of the moister content except the case of heating temperature of $900^{\circ} \mathrm{C}$. In addition, $\mathrm{H}_{2}$ is weakly dependent on the moisture content and increases slightly with the heating temperature. As a result, combined compositions of $\mathrm{CH}_{4}$ and $\mathrm{H}_{2}$ at above $700^{\circ} \mathrm{C}$ are almost constant and nearly $55 \%$, while $\mathrm{CO}_{2}$ and $\mathrm{CO}$ are the rest gas components and total volume must be almost constant. Enhancement of moisture results in increase of $\mathrm{CO}_{2}$ and decrease of $\mathrm{CO}$ at every temperature. It may be considered that the water-gas shift reaction, namely $\mathrm{CO}+$ $\mathrm{H}_{2} \mathrm{O} \rightarrow \mathrm{CO}_{2}+\mathrm{H}_{2}$ is promoted by enhancement of moister and as a result, $\mathrm{CO}$ is converted to $\mathrm{CO}_{2}$. On the other hand, high heating temperature yields decrease in $\mathrm{CO}_{2}$ and eventually increase in combustible gases. The maximum combustible gas yield, $77 \%$, is produced at $900^{\circ} \mathrm{C}$ and $0 \%$ moisture, which is $23 \%$ higher than that at $600^{\circ} \mathrm{C}$.

Yield of each gas component is calculated as volume per unit mass of feedstock from total gas yield and gas component ratio, and is shown in Figure 5. Combustible gas yield besides $\mathrm{CO}_{2}$ at $900^{\circ} \mathrm{C}$ is around three times higher than that at $600^{\circ} \mathrm{C}$. The yield of $\mathrm{CH}_{4}$ having high heating value is insusceptible against moisture content 

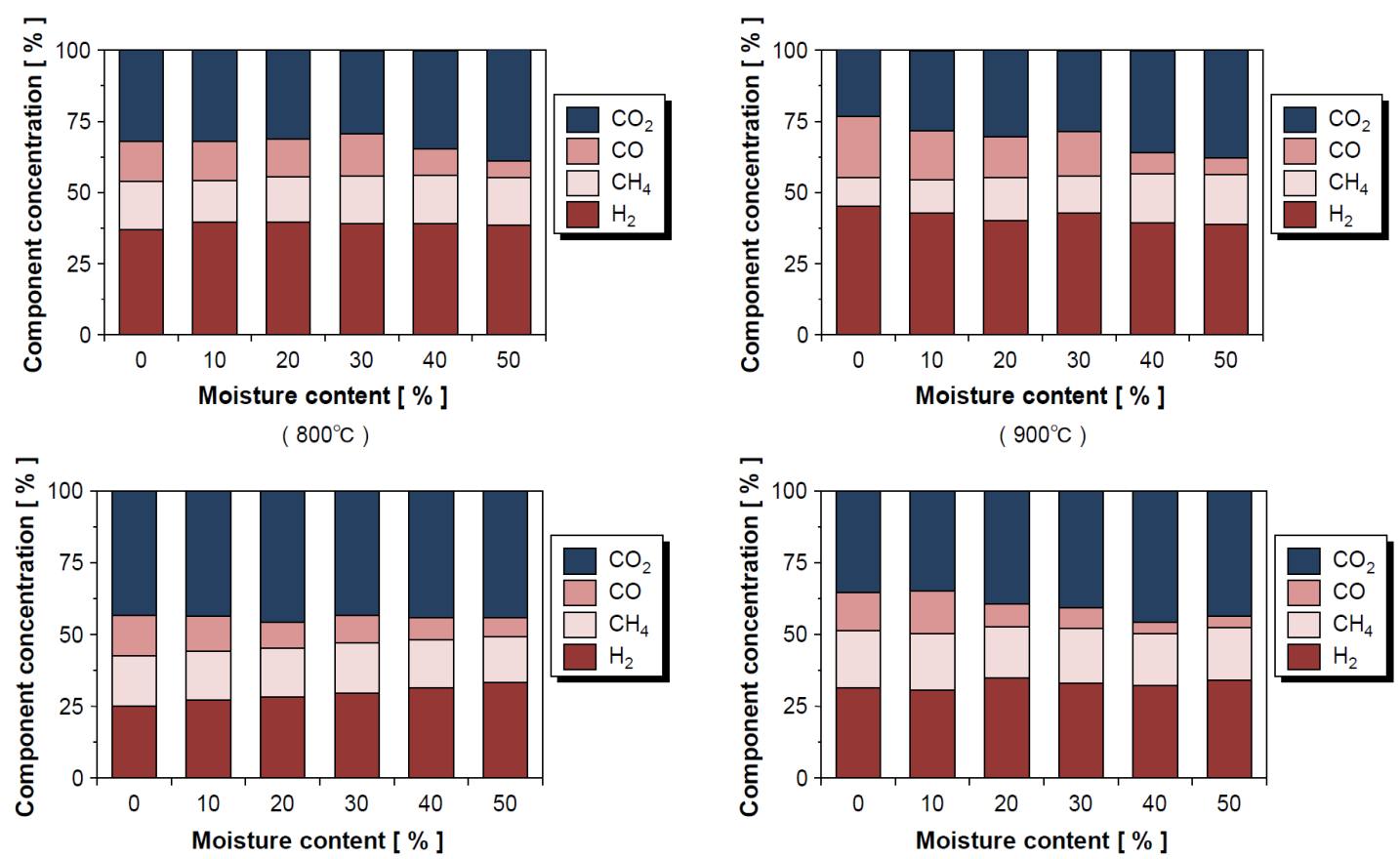

$\left(600^{\circ} \mathrm{C}\right.$ )

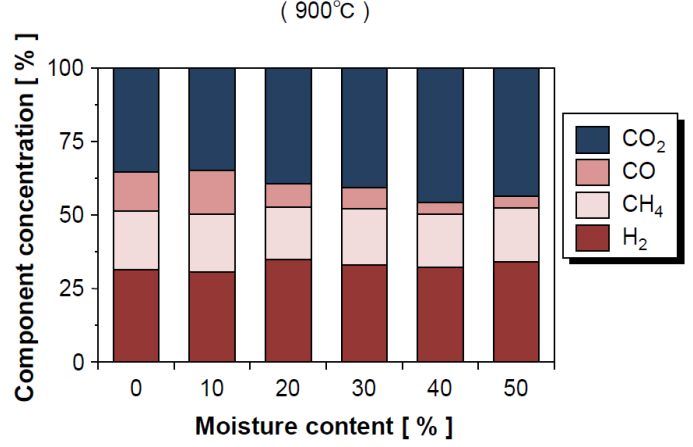

$\left(700^{\circ} \mathrm{C}\right.$ )

Figure 4. Component ratio of generated gas.
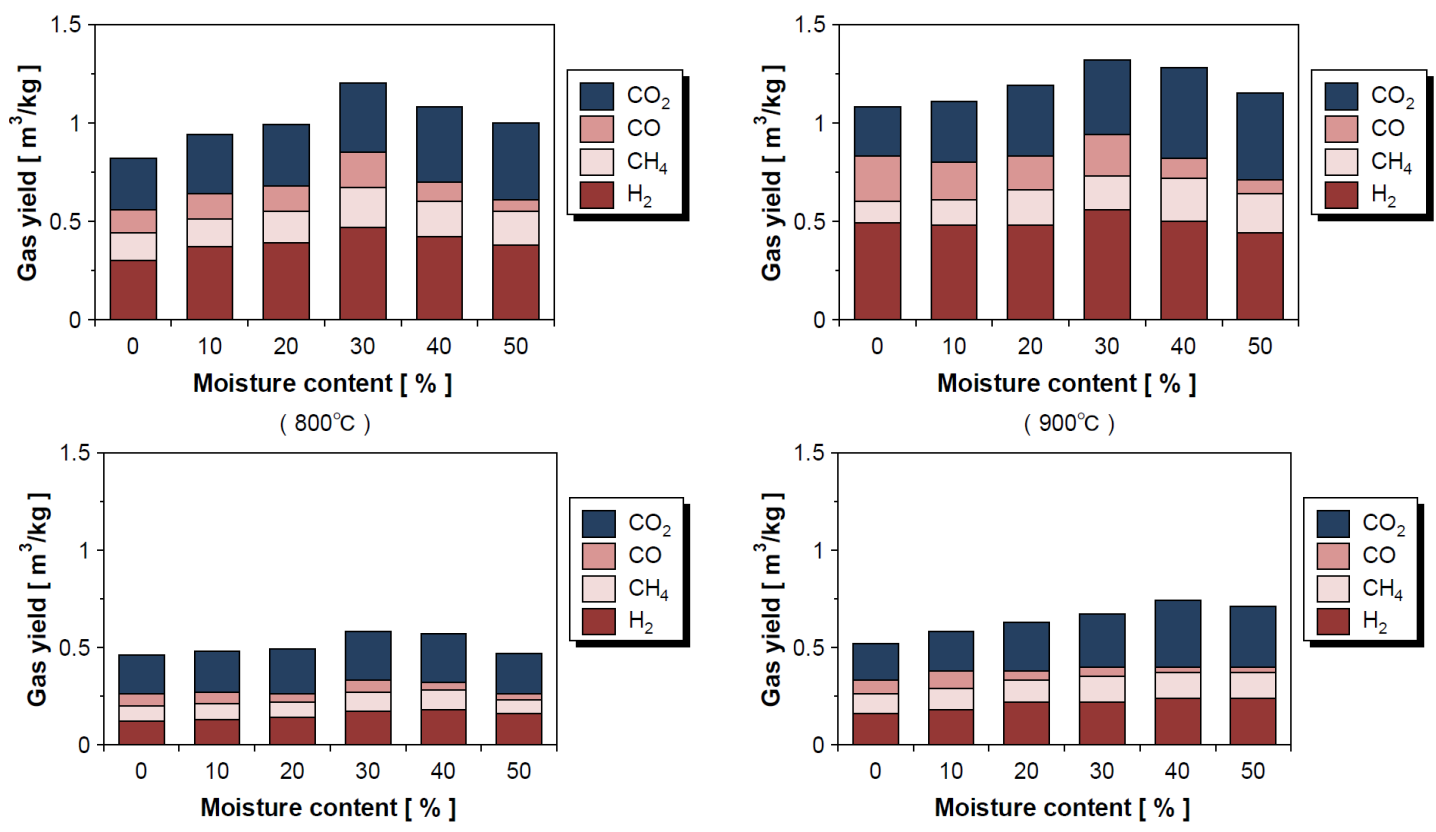

$\left(600^{\circ} \mathrm{C}\right)$

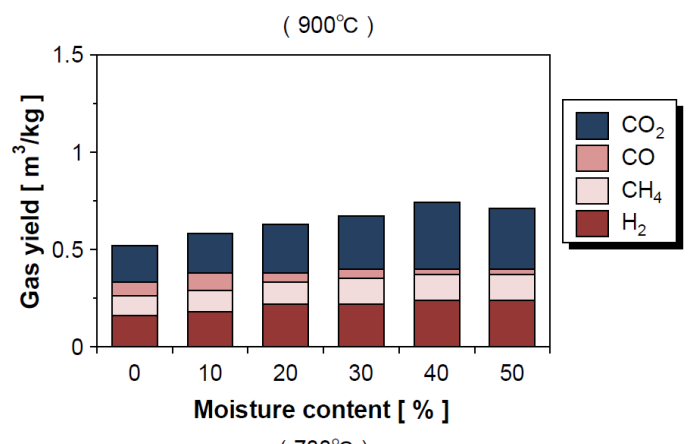

$\left(700^{\circ} \mathrm{C}\right)$

Figure 5. Yield for each component of generated gas per unit mass of feedstock.

and increases with the heating temperature up to $800^{\circ} \mathrm{C}$. At the heating temperature of $900^{\circ} \mathrm{C}$, the maximum yield of $\mathrm{CH}_{4}$ is $0.22 \mathrm{~m}^{3} / \mathrm{kg}$ for $40 \%$ moisture. At the heating temperature of $800^{\circ} \mathrm{C}$ and $900^{\circ} \mathrm{C}$, the combustible gas yield decreases as the moisture exceeds $30 \%$. Combustible gas yield reaches the peak, $0.94 \mathrm{~m}^{3} / \mathrm{kg}$ at $900^{\circ} \mathrm{C}$ and $30 \%$ moisture. At $800^{\circ} \mathrm{C}$, the largest combustible gas yield is $0.85 \mathrm{~m}^{3} / \mathrm{kg}$ for $30 \%$ moisture and is higher than the yields at $900^{\circ} \mathrm{C}$ and moisture of other than $30 \%$. Moisture content of more than $30 \%$ and heating temperature of more than $800^{\circ} \mathrm{C}$ produce less gas yield that results from reduction of $\mathrm{CO}$ yield and $\mathrm{H}_{2}$ yield. The 
reduction in total gas yield is less than the reduction in combustion gas yield. Therefore, it is considered that decomposition reaction is suppressed due to increase in the chamber pressure resulted from vapored moisture, but the suppression is predominant over water gas shift reaction by moisture effect.

As compared with gas yield by rotary kiln gasifier using an indirect heating method, it should be noted that the current closed gasifier chamber produces almost same volume percent of $\mathrm{CH}_{4}, 2.5$ times larger volume percent of $\mathrm{CO}_{2}$ and $\mathrm{H}_{2}$, and quarter times smaller volume percent of $\mathrm{CO}$ [29]. Downdraft type of gasifier and updraft type of gasifier that use a direct heating method with some air intake to burn biomass partially, produce gas yields containing $\mathrm{N}_{2}$. Comparing the gas component yields produced by the current system with those produced by the downdraft or updraft type of gasifier, it should be noted that the current system produces 2 times larger volume percent of $\mathrm{CH}_{4}$ and smaller volume percent of $\mathrm{CO}_{2}$ [30]. The current closed chamber gasifier is characterized as $\mathrm{H}_{2}$-rich gasifier, because the $\mathrm{H}_{2}$ yield is significantly high as compared with that by other type gasifiers.

\subsection{Heating Value of Generated Gas}

Combustion of $\mathrm{H}_{2}, \mathrm{CO}$ and $\mathrm{CH}_{4}$ generates heat of $286 \mathrm{MJ} / \mathrm{kmol}, 284 \mathrm{MJ} / \mathrm{kmol}$ and $891 \mathrm{MJ} / \mathrm{kmol}$, respectively. Gross heating value of generated gas yields per unit mass of feedstock can be calculated from these values and is shown in Figure 6. Cold gas efficiency is defined as a ratio of gross heating value of generated gas to heating value of feedstock. At $600^{\circ} \mathrm{C}$, averaged gross heating value is $5.4 \mathrm{MJ} / \mathrm{kg}$, and the cold gas efficiency is lower than $30 \%$. When heating temperature is higher than $800^{\circ} \mathrm{C}$, gross heating value is around twice higher than that at $600^{\circ} \mathrm{C}$ and is larger than $9 \mathrm{MJ} / \mathrm{kg}$. The cold gas efficiency exceeds $50 \%$. Gross heating value is maximized at $900^{\circ} \mathrm{C}$ and $30 \%$ moisture content where the largest gas yield is produced. The gross heating value is $15.1 \mathrm{MJ} / \mathrm{kg}$ and the cold gas efficiency is enhanced to $84 \%$.

Specific heating value of generated gas per unit volume is shown in Figure 7. The values vary slightly over whole heating temperature and moisture. Because combustible gas ratio is reduced due to increase in $\mathrm{CO}_{2}$ ratio, specific heating value is gradually declined as the moisture content increases. The specific heating value at $600^{\circ} \mathrm{C}$ and $900^{\circ} \mathrm{C}$ is lower than that at other heating temperature. This is because combustible gas ratio is low due to high $\mathrm{CO}_{2}$ ratio at $600^{\circ} \mathrm{C}$, and due to low ratio of $\mathrm{CH}_{4}$, which has the highest heating value, at $900^{\circ} \mathrm{C}$. In general, most of gases generated from woody biomass by direct heating are classified to low calorie gas. At $700^{\circ} \mathrm{C}$ and $0 \%$ and $10 \%$ moisture content, and $800^{\circ} \mathrm{C}$ and $30 \%$ moisture content, specific heating values of the generated gas exceed $12 \mathrm{MJ} / \mathrm{m}^{3}$ and the gas produced by the current gasifier is classified into middle calorie gas.

\section{Conclusions}

In this study, indirect gasification experiment was carried out using thin robber wood pieces as gasification feedstock in the closed gasifier chamber proposed by the current authors. Experiments were carried out for various heating temperature and moisture contents, and following conclusions are obtained.

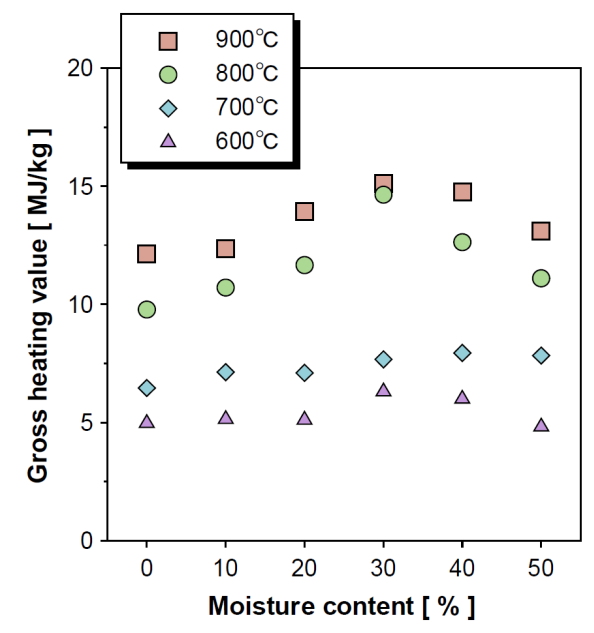

Figure 6. Gross heating value of generaed gas per unit mass of feedstock. 


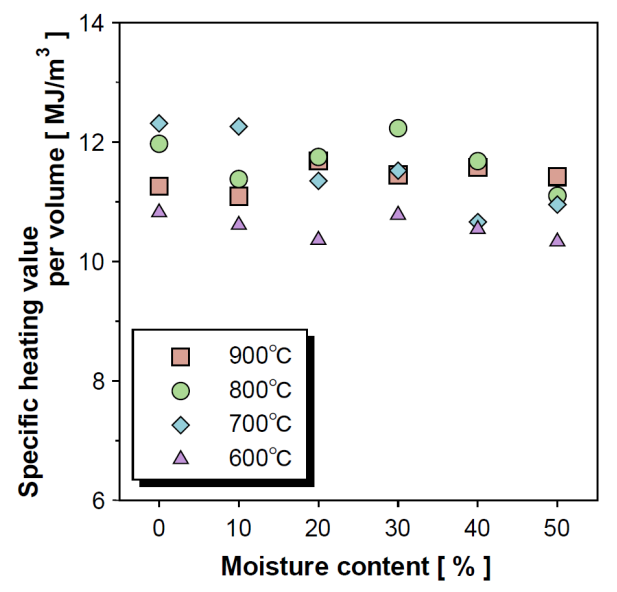

Figure 7. Specific heating value of generated gas per volume.

- Adding water as gasification agent brings increase in gas yield by promotion of gasification reaction. When heating temperature is high and moisture content is high, gas yield decreases due to suppression in gasification and high pressure in the gasifier chamber.

- $\mathrm{CH}_{4}$ ratio of gas yield is insusceptible against heating temperature and moisture content. Sum of $\mathrm{H}_{2}$ and $\mathrm{CH}_{4}$ ratios is almost constant over all the experimental conditions. Higher moisture content brings higher $\mathrm{CO}_{2}$ ratio and lower $\mathrm{CO}$ ratio. In addition, high heating temperature decreases $\mathrm{CO}_{2}$ ratio, and then increases combustible gas ratio.

- Gross heating value of generated gas per unit mass of biomass is higher than $9 \mathrm{MJ} / \mathrm{kg}$, and cold gas efficiency exceeds $50 \%$ at heating temperature of higher than $800^{\circ} \mathrm{C}$. On the other hand, specific heating value per volume at heating temperature of $900^{\circ} \mathrm{C}$ falls below that at $800^{\circ} \mathrm{C}$, because combustible gas components other than $\mathrm{CH}_{4}$ having the highest heating value are major. The maximum specific heating value of gas yield can surpass $12 \mathrm{MJ} / \mathrm{m}^{3}$, which is the lower limit for a middle calorie gas, and thus it is definitely predicated that the developed gasifier can produce middle calorie gas.

\section{References}

[1] (2015) Southeast Asia Energy Outlook 2015. International Energy Agency Publications, Paris.

[2] (2015) The 4th ASEAN Energy Outlook. ASEAN Centre for Energy, Indonesia.

[3] (2014) Handbook of Energy \& Economic Statistics of Indonesia 2014. Ministry of Energy and Mineral Resources of Indonesia, Jakarta.

[4] Hasan, M.H., Mahlia, T.M.I. and Nur, H. (2012) A Review on Energy Scenario and Sustainable Energy in Indonesia. Renewable and Sustainable Energy Reviews, 16, 2316-2328. http://dx.doi.org/10.1016/j.rser.2011.12.007

[5] (2014) Electricity Statistics Number 27 - 2014. Ministry of Energy and Mineral Resources of Indonesia, Jakarta.

[6] Simone, M., Barontini, F., Nicolella, C. and Tognotti, L. (2012) Gasification of Pelletized Biomass in a Pilot Scale Downdraft Gasifier. Bioresource Technology, 116, 403-412. http://dx.doi.org/10.1016/j.biortech.2012.03.119

[7] Ma, Z., Zhang, Y., Zhang, Q., Qu, Y., Zhou, J. and Qin, H. (2012) Design and Experimental Investigation of a 190 $\mathrm{kW}_{\mathrm{e}}$ Biomass Fixed Bed Gasification and Polygeneration Pilot Plant Using a Double Air Stage Downdraft Approach. Energy, 46, 140-147. http://dx.doi.org/10.1016/j.energy.2012.09.008

[8] Guo, F., Dong, Y., Dong, L. and Guo, C. (2014) Effect of Design and Operating Parameters on the Gasification Process of Biomass in a Downdraft Fixed Bed: An Experimental Study. International Journal of Hydrogen Energy, 39, 5625-5633. http://dx.doi.org/10.1016/j.ijhydene.2014.01.130

[9] Gunarathne, D.S., Mueller, A., Fleck, S., Kolb, T., Chmielewski, J.K., Yang, W. and Blasiak, W. (2014) Gasification Characteristics of Steam Exploded Biomass in an Updraft Pilot Scale Gasifier. Energy, 71, 496-506. http://dx.doi.org/10.1016/j.energy.2014.04.100

[10] Pletka, R., Brown, R.C. and Smeenk, J. (2001) Indirectly Heated Biomass Gasification Using a Latent Heat Ballast-1: Experimental Evaluations. Biomass and Bioenergy, 20, 297-305. http://dx.doi.org/10.1016/S0961-9534(00)00088-X

[11] Li, X.T., Grace, J.R., Lim, C.J., Watkinson, A.P., Chen, H.P. and Kim, J.R. (2004) Biomass Gasification in a Circulat 
ing Fluidized Bed. Biomass and Bioenergy, 26, 171-193. http://dx.doi.org/10.1016/S0961-9534(03)00084-9

[12] Campoy, M., Gómez-Barea, A., Vidal, F.B. and Ollero, P. (2009) Air-Steam Gasification of Biomass in a Fluidised Bed: Process Optimisation by Enriched Air. Fuel Processing Technology, 90, 677-685. http://dx.doi.org/10.1016/j.fuproc.2008.12.007

[13] Kern, S., Halwachs, M., Kampichler, G., Pfeifer, C., Pröll, T. and Hofbauer, H. (2012) Rotary Kiln Pyrolysis of Straw and Fermentation Residues in a 3MW Pilot Plant-Influence of Pyrolysis Temperature on Pyrolysis Product Performance. Journal of Analytical and Applied Pyrolysis, 97, 1-10. http://dx.doi.org/10.1016/j.jaap.2012.05.006

[14] Iovane, P., Donatelli, A. and Molino, A. (2013) Influence of Feeding Ratio on Steam Gasification of Palm Shells in a Rotary Kiln Pilot Plant. Experimental and Numerical Investigations. Biomass and Bioenergy, 56, 423-431. http://dx.doi.org/10.1016/j.biombioe.2013.05.025

[15] Yamasaki, Y., Kanno, M., Taura, Y. and Kaneko, S. (2009) Study on Biomass Gas HCCI Engine. SAE Technical Paper, 2009-32-0066.

[16] Sato, S., Yamasaki, Y., Kawamura, H. and Iida, N. (2005) Research on the Influence of Hydrogen and Carbon Monoxide on Methane HCCI Combustion. JSME International Journal Series B, 48, 725-734. http://dx.doi.org/10.1299/jsmeb.48.725

[17] Bika, A.S., Franklin, L. and Kittelson, D.B. (2012) Homogeneous Charge Compression Ignition Engine Operating on Synthesis Gas. International Journal of Hydrogen Energy, 37, 9402-9411. http://dx.doi.org/10.1016/j.ijhydene.2012.03.014

[18] Bhaduri, S., Contino, F., Jeanmart, H. and Breuer, E. (2015) The Effects of Biomass Syngas Composition, Moisture, Tar Loading and Operating Conditions on the Combustion of a Tar-Tolerant HCCI (Homogeneous Charge Compression Ignition) Engine. Energy, 87, 289-302. http://dx.doi.org/10.1016/i.energy.2015.04.076

[19] Sahoo, B.B., Sahoo, N. and Saha, U.K. (2012) Effect of $\mathrm{H}_{2}$ : CO Ratio in Syngas on the Performance of a Dual Fuel Diesel Engine Operation. Applied Thermal Engineering, 49, 139-146. http://dx.doi.org/10.1016/j.applthermaleng.2011.08.021

[20] Azimov, U., Tomita, E., Kawahara, N. and Harada, Y. (2011) Effect of Syngas Composition on Combustion and Exhaust Emission Characteristics in a Pilot-Ignited Dual-Fuel Engine Operated in PREMIER Combustion Mode. International Journal of Hydrogen Energy, 36, 11985-11996. http://dx.doi.org/10.1016/j.ijhydene.2011.04.192

[21] Hagos, F.Y., Aziz, A.R.A. and Sulaiman, S.A. (2014) Syngas $\left(\mathrm{H}_{2} / \mathrm{CO}\right)$ in a Spark-Ignition Direct-Injection Engine. Part 1: Combustion, Performance and Emissions Comparison with CNG. International Journal of Hydrogen Energy, 39, 17884-17895. http://dx.doi.org/10.1016/j.ijhydene.2014.08.141

[22] Yamasaki, Y., Kanno, M., Suzuki, Y. and Kaneko, S. (2013) Development of an Engine Control System Using City Gas and Biogas Fuel Mixture. Applied Energy, 101, 465-474. http://dx.doi.org/10.1016/j.apenergy.2012.06.013

[23] Homma, H., Oka, M. and Nishida, N. (2012) Effect of Moisture Content for Indirect Gasification of Hinoki in Closed Gasifier System. Journal of the Forest Biomass Utilization Society, 7, 75-81. (In Japanese)

[24] Homma, H., Homma, H., Yusrizal and Idris, M. (2013) Wood Pyrolysis in Pre-Vacuum Chamber. Journal of Sustainable Bioenery Systems, 3, 243-249. http://dx.doi.org/10.4236/jsbs.2013.34033

[25] Jayah, T.H., Aye, L., Fuller, R.J. and Stewart, D.F. (2003) Computer Simulation of a Downdraft Wood Gasifier for Tea Drying. Biomass and Bioenergy, 25, 459-469. http://dx.doi.org/10.1016/S0961-9534(03)00037-0

[26] Sheth, P.N. and Babu, B.V. (2009) Experimental Studies on Producer Gas Generation from Wood Waste in a Downdraft Biomass Gasifier. Bioresource Technology, 100, 3127-3133. http://dx.doi.org/10.1016/j.biortech.2009.01.024

[27] Kaewluan, S. and Pipatmanomai, S. (2011) Potential of Synthesis Gas Production from Rubber Wood Chip Gasification in a Bubbling Fluidised Bed Gasifier. Energy Conversion and Management, 52, 75-84. http://dx.doi.org/10.1016/j.enconman.2010.06.044

[28] Naruse, I., Ueki, Y., Isayama, T., Shinba, T., Kihedu, J.H. and Yoshiie, R. (2010) Reaction Characteristic of Woody Biomass with $\mathrm{CO}_{2}$ and $\mathrm{H}_{2} \mathrm{O}$. Tetsu-to-Hagane, 96, 150-155. (In Japanese) http://dx.doi.org/10.2355/tetsutohagane.96.150

[29] Efika, C.E., Wu, C. and Williams, P.T. (2012) Syngas Production from Pyrolysis-Catalytic Steam Reforming of Waste Biomass in a Continuous Screw Kiln Reactor. Journal of Analytical and Applied Pyrolysis, 95, 87-94. http://dx.doi.org/10.1016/j.jaap.2012.01.010

[30] Skoulou, V., Zabaniotou, A., Stavropoulos, G. and Sakelaropoulos, G. (2008) Syngas Production from Olive Tree Cuttings and Olive Kernels in a Downdraft Fixed-Bed Gasifier. International Journal of Hydrogen Energy, 33, 1185-1194. http://dx.doi.org/10.1016/j.ijhydene.2007.12.051 